\title{
PENGARUH TRANSFORMASI ORGANISASI TERHADAP KINERJA DENGAN MOTIVASI DAN KOMPENSASI SEBAGAI VARIABEL MEDIASI PADA PERSONIL PROJECT MANAGEMENT OFFICE PT PERUSAHAAN GAS NEGARA TBK.
}

\author{
Armynas Handyas Wijayatma ${ }^{1}$, Liswandi ${ }^{2}$ \& Sugilar $^{3}$ \\ 1Program Pascasarjana, Universitas Terbuka \\ ${ }^{2}$ School of Business, President University \\ ${ }^{3}$ Program Pascasarjana, Universitas Terbuka \\ *Email korespondensi: armynas.handyas@gmail.com
}

\begin{abstract}
The main objective of this study is to examine and analyze the effect of organizational transformation on performance with motivation and compensation as mediating variables in the project management office ("PMO") personnel of PT Perusahaan Gas Negara Tbk. ("PGN") by using a quantitative descriptive approach. The data in this study were obtained from PMO organic employees who work at PGN. The total population of PMO organic employees at the time the research was conducted was 118 (one hundred and eighteen) people. While the samples taken in this study were organic employees with positions ranging from 'Staff' to 'Vice President'. The data analysis in this study used an alternative method of structural equation modeling (SEM), namely partial least squares (PLS). The first stage in this research is to test the validity of each variable's statement indicator along with their reliability. The second stage examines the relationship between the existing hypotheses for both direct effects and indirect effects between research variables. The results of this study indicate that PGN's organizational transformation has a significant effect on PMO employee performance, either through motivation or compensation as mediation or without the mediation.
\end{abstract}

Keywords: Performance, Compensation, Motivation, Organizational Transformation

(C) The Author(s) 2021

DOI: $10.36407 /$ jmsab.v4i2.401

Jurnal

Manajemen

Strategi dan

Aplikasi

Bisnis,

Vol 4, No. 2,

2021,

pp. 519 - 532

eISSN 2655-

$237 \mathrm{X}$

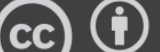

CC BY: This license allows reusers to distribute, remix, adapt, and build upon the material in any medium or format, so long as attribution is given to the creator. The license allows for commercial use. 


\section{PENDAHULUAN}

PT Perusahaan Gas Negara Tbk. ("PGN") sebagai salah satu perusahaan nasional yang bergerak dalam bidang pengelolaan energi gas bumi telah terdaftar pada Bursa Efek Indonesia dengan kode perdagangan 'PGAS' pada saat ini berupaya menangkap peluang penyediaan dan pemenuhan permintaan energi gas bumi dengan menyalurkan gas bumi dari sumber-sumber pasokan kepada pengguna gas bumi melalui metode pipa dan beyond pipeline lainnya berupa LNG (Liquified Natural Gas), CNG (Compressed Natural Gas) serta dukungan layanan lainnya berupa jaringan telekomunikasi fiber optic, rekayasa engineering hingga penyediaan perumahan yang menggunakan gas bumi sebagai bahan bakar untuk keperluan rumah tangga.

Dalam perjalanannya pada tahun 2018, PGN sebagai sebuah organisasi yang terus tumbuh dan berkembang tidak luput dari faktor-faktor eksternal organisasi. Termasuk ditetapkannya PGN sebagai subholding gas sebagai salah satu bentuk transformasi organisasi pasca dibentuknya holding migas. Konsekuensi logis sebagai tindak lanjut dari proses transformasi organisasi tersebut adalah perubahan struktur organisasi PGN yang dibentuk dalam mendukung tujuan korporasi yang ditetapkan oleh PT Pertamina (Persero) sebagai holding migas sesuai amanah Peraturan Pemerintah No. 6 Tahun 2018 tentang 'Penambahan Penyertaan Modal Negara Republik Indonesia Kedalam Modal Saham Perusahaan Perseroan (Persero) PT Pertamina'. Hal tersebut berdampak pada PGN yang semula merupakan BUMN, menjadi subholding gas yang dimiliki oleh PT Pertamina (Persero).

Pembentukan subholding gas tersebut diharapkan dapat meningkatkan penyediaan gas bumi serta masifnya pengembangan dan pembangunan infrastruktur penyaluran gas bumi dalam menunjang pemanfaatan gas bumi sebagai sumber energi ramah lingkungan dalam mendukung target pertumbuhan ekonomi yang telah dicanangkan oleh pemerintah Indonesia. Pada sisi lainnya peningkatan pemanfaatan gas bumi juga diharapkan dapat mengurangi impor LPG yang saat ini mengakibatkan neraca perdagangan Indonesia menjadi negatif. Pembangunan infrastruktur gas bumi sebagaimana yang telah disebutkan sebelumnya, merupakan critical key-factor dalam menyalurkan gas bumi dari sumber pasokan gas bumi yang pada umumnya berada di daerah remote kepada pengguna-pengguna gas bumi yang pada umumnya locus demand tersebut berada pada kawasan industri, pusat perekonomian dan perkotaan.

Berdasarkan fakta tersebut, pembangunan infrastruktur gas bumi dipengaruhi dengan berbagai tantangan yang dapat berdampak pada keberhasilan pelaksanaan proyek antara lain berupa pembebasan lahan, perizinan, pelaksanaan proyek, sumber daya manusia ('SDM'), kondisi lingkungan, regulasi baik tingkat pusat maupun daerah hingga kesehatan, keamanan dan keselamatan kerja ('K3'). Selanjutnya berdasarkan Keputusan Direksi PGN No. 020301.K/OT/INT/2019 tertanggal 20 Agustus 2019, Project Management Office ('PMO') ditetapkan sebagai satuan kerja yang memiliki fungsi pengelolaan proyek pengembangan infrastruktur gas bumi yang dilakukan oleh PGN termasuk melakukan sinkronisasi kegiatan pelaksanaan proyek serta melakukan pemantauan pengelolaan investasi. 


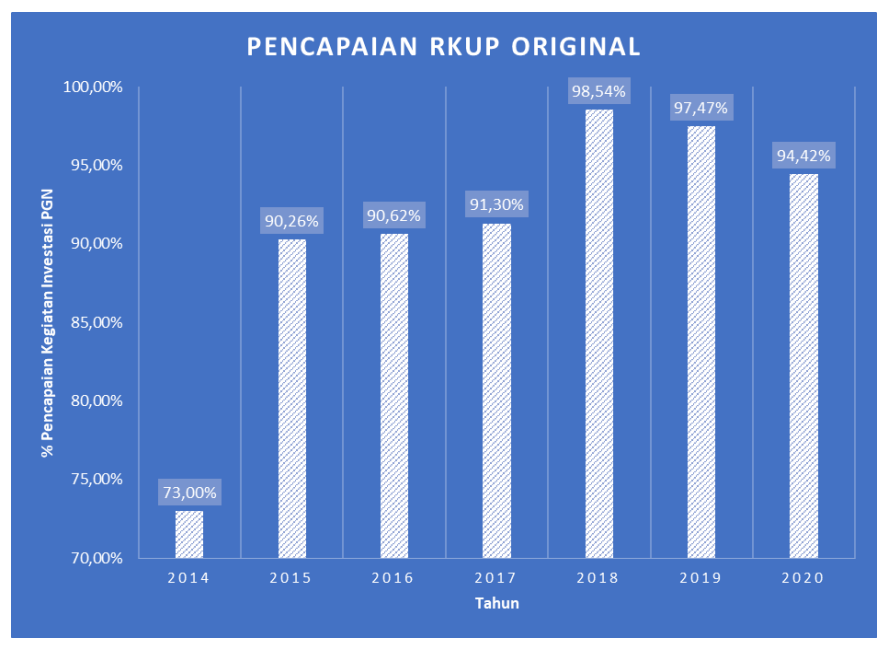

\section{Gambar 1.}

Persentase Pencapaian Kegiatan Investasi PMO Tahun 2014 - 2020

Pencapaian kinerja dalam melakukan pengembangan dan pembangunan infrastruktur gas bumi yang dilakukan oleh PMO pada tahun 2019 dan 2020 mengalami penurunan dibandingkan pada tahun-tahun sebelumnya. Apabila pada tahun 2018 tingkat penyerapan investasi Rencana Kerja Usulan Proyek ('RKUP') original yang menjadi salah satu KPI (Key Performance Indicator) target PMO dapat mencapai 98,54\% akan tetapi pada tahun 2019 mengalami penurunan di angka 97,47\% dan kemudian tahun 2020 mengalami penurunan kembali menjadi $94,42 \%$.

Keberhasilan pembangunan infrastruktur gas bumi salah satunya dipengaruhi oleh kinerja personil dalam menyelesaikan kegiatan keproyekan yang telah ditetapkan oleh perusahaan. Latief (2012:63) menyampaikan bahwa "kinerja adalah hasil kerja yang dihasilkan oleh pegawai atau perilaku nyata yang ditampilkan sesuai dengan perannya di organisasi". Sedangkan Syaifuddin (2018:62) menyampaikan bahwa "pada dasarnya kinerja merupakan sesuatu hal yang bersifat individual, karena setiap pegawai memiliki tingkat kemampuan yang berbeda dalam mengerjakan tugasnya" yang dalam penelitian ini kinerja dikaitkan dengan dukungan personil dalam membangun jaringan infrastruktur gas bumi dengan pendekatan yang lebih profesional terkait jaminan keamanan (safety), kualitas (quality) dan ketepatan waktu (schedule) pelaksanaan pekerjaan dalam kegiatan keproyekan di PGN selaku subholding gas.

Kinerja personil selanjutnya dapat dipengaruhi oleh motivasi, sebagaimana disampaikan oleh Sanuddin \& Widjojo (2013) menyebutkan perlunya motivasi kerja yang tinggi dari masingmasing pegawai untuk meningkatkan produktifitas perusahaan. Sedangkan menurut penelitian yang dilakukan Fadilah (2018) menjelaskan adanya fenomena motivasi kerja berpengaruh positif tetapi tidak signifikan terhadap kinerja pegawai aparatur sipil pada salah satu pemerintah kota. Selanjutnya kinerja organisasi juga dapat dipengaruhi oleh faktor kompensasi. Maulana (2020) menyampaikan bahwa kompensasi yang diberikan organisasi akan memuaskan dan memotivasi pegawai untuk mencapai sasaran organisasi. Penelitian yang dilakukan oleh Subakti (2013) menyebutkan adanya fenomena rendahnya kinerja karyawan cafe ' $X$ ' karena faktor gaji dan tidak adanya insentif yang diberikan oleh manajemen. Dalam proses pembentukan subholding gas pada tahun 2018, secara langsung menuntut top management PGN untuk mengambil langkah-langkah strategis yang menyebabkan terjadinya perubahan struktur organisasi dan proses bisnis. Siagian (2012) menyebutkan atas langkah strategis perusahaan dalam memperbaiki proses bisnis dan restrukturisasi organisasi perusahaan, setidaknya terdapat tiga faktor organisasional yang terdampak terhadap cara perusahaan berfungsi dan berinteraksi dengan lingkungan eksternal dan internal yaitu struktur organisasi, proses bisnis dan budaya organisasi. Implementasi perubahan struktur organisasi dan proses bisnis dalam waktu yang cukup singkat (kurang dari satu tahun) merupakan salah bentuk dari transformasi organisasi. Susanto (2016) menyampaikan bahwa transformasi organisasi adalah suatu proses perubahan organisasi berpindah maupun 
berubah dari keadaan eksisting pada saat ini menuju kepada keadaan yang ingin dicapai dalam rangka meningkatkan efektifitas, efisiensi dan tercapainya tujuan organisasi dalam jangka waktu yang telah ditetapkan.

Aspek keterbaruan (novelty) penelitian ini terletak pada model penelitian yang menggunakan variabel mediasi berganda yaitu motivasi dan kompensasi dalam mempengaruhi hubungan transformasi organisasi sebagai variabel bebas dan kinerja sebagai variabel terikatnya, disamping masih terbatasnya penelitian yang memberikan bukti empiris pengaruh implementasi transformasi organisasi terhadap pencapaian kinerja perusahaan. Adapun latar belakang penetapan motivasi dan kompensasi sebagai variabel mediasi dalam penelitian ini dengan mempertimbangkan faktor dominan yang ditemukan dari hasil survei pra-penelitian sebelumnya. Adanya urgensi atas permasalahan yang teridentifikasi pada survei pencapaian transformasi organisasi oleh Standish Group International dalam Susanto (2016) dan realita penurunan kinerja PMO sebagai bagian subholding gas yang merupakan unsur tidak terpisahkan dari PT Pertamina (Persero) sebagai salah satu BUMN terkemuka di Indonesia dalam penelitian ini, diharapkan dapat memberikan pandangan teraktual atas implementasi transformasi organisasi terhadap kinerja perusahaan dalam lingkup manajerial SDM.

Sehingga atas peran strategis transformasi organisasi dan mengacu pada hasil penelitianpenelitian terdahulu, maka penelitian ini akan mencoba menganalisis pengaruh dari transformasi organisasi yang ditetapkan oleh top management PGN dalam rangka dibentuknya subholding gas terhadap kinerja pegawai pada satuan kerja PMO yang ditetapkan menjadi obyek penelitian.

\section{KAJIAN PUSTAKA}

\section{Transformasi Organisasi}

Dalam menghadapi derasnya arus perubahan yang masif dan pervasif pada saat ini, sebuah organisasi baik entitas swasta, BUMN maupun pemerintahan selalu dituntut untuk dapat menyesuaikan diri (adaptive) dengan perkembangan teknologi, adanya disrupsi maupun tuntutan dari pemangku kepentingan (stakeholder). Siagian (2012) menyampaikan adanya perbedaan konsep antara 'Pengembangan Organisasi' dengan 'Transformasi Organisasi', pada dasarnya "pengembangan organisasi menggunakan pendekatan gradual (bertahap) dalam mewujudkan perubahan, termasuk perubahan yang bersifat strategis dengan sorotan perhatian dan upaya pada proses pengembangan yang pelaksanaannya bersifat partisipatif", sedangkan transformasi organisasi memiliki ciri khas bahwa upaya perubahan yang dilakukan bersifat signifikan dan mendadak yang diarahkan pada tiga faktor organisasi, antara lain: (1) Sebagian maupun keseluruhan struktur organisasi dengan berpedoman pada kebutuhan perusahaan dalam mengantisipasi kondisi pada saat transformasi ditentukan sebagai langkah strategis perusahaan, (2) Proses manajemen yang diterapkan pada perusahaan dalam menghasilkan produk maupun jasa, (3) Budaya organisasi eksisting yang telah menjadi bagian tidak terpisahkan dalam kegiatan operasional perusahaan.

Dikarenakan sifat dan sasaran yang diharapkan oleh perusahaan untuk memperoleh daya tahan terhadap organisasi dalam memenangkan persaingan dengan kompetitor, maka perubahan yang ingin diwujudkan oleh top management melalui implementasi transformasi organisasi akan berbeda dengan tahapan dalam pengembangan organisasi yang lebih bersifat partisipatif. Sebagai contoh pada negara-negara yang sudah maju sektor industrinya, pengertian transformasi organisasi terkait erat dengan perubahan yang lebih bersifat pengambil alihan, penggabungan baik melalui merger maupun akuisisi, penutupan sarana atau prasarana dengan tujuan melakukan efisiensi pada skala besar, pemutusan hubungan kerja personil yang sudah tidak produktif hingga restrukturisasi manajemen yang sifatnya masif (Siagian, 2012).

\section{Motivasi}

Syaifuddin (2018) menyampaikan bahwa motivasi berpengaruh besar terhadap produktivitas yang dihasilkan oleh karyawan dalam dalam bekerja. Syaifuddin (2018) juga memberikan pandangan pengaruh motivasi terhadap kinerja yang dilandasi asumsi melakukan suatu pekerjaan tanpa adanya motivasi, maka karyawan akan cepat jenuh yang disebabkan tidak adanya faktor pendorong agar karyawan tetap memiliki semangat untuk bekerja. Motivasi 
dapat dianggap sebagai hal yang sederhana dikarenakan pada dasarnya manusia sebagai individu mudah diberikan motivasi yaitu dengan memberikan apa yang di-inginkannya, akan tetapi motivasi dapat menjadi sangat kompleks apabila menyangkut kepada hal maupun sesuatu yang dianggap sangat penting kepada individu tertentu. Syaifuddin (2018) menjelaskan bahwa pada hakikatnya motivasi kerja merupakan daya penggerak seseorang melakukan suatu aktivitas untuk memenuhi kebutuhannya.

\section{Kompensasi}

Handoko (2015) menyampaikan bahwa kompensasi merupakan pendapatan yang diperoleh dari pekerjaannya. Pemberian kompensasi merupakan fungsi strategis SDM yang berdampak signifikan terhadap fungsi SDM lainnya. Kompensasi berupa pemenuhan kebutuhan finansial juga mempengaruhi strategi organisasi secara keseluruhan karena kompensasi berdampak besar pada kepuasan kerja, produktivitas, pergantian pegawai dan proses lainnya dalam organisasi. Organisasi atau perusahaan memandang kompensasi sangat penting karena kompensasi mencerminkan upaya organisasi untuk memelihara dan meningkatkan kesejahteraan pegawainya (Handoko, 2015).

\section{Kinerja}

Kinerja yang optimal sangat dibutuhkan untuk meningkatkan produktivitas dan menjaga kelangsungan hidup perusahaan. Setiap perusahaan tidak akan pernah luput dari hal pemberian kompensasi yang merupakan salah satu faktor penting dalam menciptakan motivasi kerja kepada personilnya dikarenakan untuk menjaga dan meningkatkan kinerja personil dibutuhkan pemenuhan kompensasi untuk mendukung motivasi yang telah ada (Latief, 2012). Dalam sudut pandang lainnya, organisasi menempatkan kinerja berdasarkan penilaian atas hasil capaian yang diperoleh unit-unit dan individu yang berada di dalam organisasi tersebut (Syaifuddin, 2018). Selanjutnya Syaifuddin (2018:69) juga menyampaikan bahwa "kinerja individu adalah dasar kinerja organisasi".

Kinerja telah menjadi terminologi penting dalam berbagai pembahasan khususnya terkait keberhasilan organisasi dan SDM dalam mencapai tujuan maupun sasaran yang telah ditetapkan. Kinerja akan selalu menjadi isu aktual dalam organisasi karena apapun jenis organisasinya, dikarenakan kinerja merupakan kunci terhadap efektifitas keberhasilan organisasi dalam melakukan kegiatannya. Indrasari (2017:50) menyebutkan definisi dari kinerja yang berasal dari kata job performance atau actual performance yang dapat diartikan prestasi kerja atau prestasi sesungguhnya yang dicapai, yaitu "kinerja adalah hasil kerja secara kualitas dan kuantitas yang dicapai oleh karyawan dalam melaksanakan tugasnya sesuai dengan tanggung jawab yang diberikan kepadanya".

\section{Pengaruh Transformasi Organisasi Terhadap Kinerja}

Implementasi transformasi organisasi memiliki pengaruh positif dan signifikan terhadap kinerja pegawai (Yursil \& Huda, 2016). Adapun tujuan utama transformasi organisasi adalah untuk mencari metode baru atau memperbaiki pemanfaatan sumber daya dan kemampuan yang dimiliki organisasi dengan maksud untuk meningkatkan kemampuan organisasi dalam menciptakan nilai tambah dan memperoleh target kinerja yang diinginkan oleh para pemangku kepentingan (Susanto, 2016).

H1. Transformasi organisasi PGN mempengaruhi kinerja PMO.

\section{Pengaruh Transformasi Organisasi Terhadap Motivasi}

Implementasi transformasi organisasi harus memperhatikan adanya dampak terhadap kepentingan personil terkait dengan kesejahteraan, pengembangan karir dan hubungan emosional maupun tekanan yang berasal dari lingkungan eksternal (Soetjipto, 2014). Faktor internal lainnya dapat berupa motivasi, tujuan, harapan dan lainnya sedangkan faktor eksternal berupa lingkungan fisik dan non-fisik perusahaan (Handoko, 2015).

H2. Transformasi organisasi PGN mempengaruhi kompensasi yang didapatkan personil PMO.

\section{Pengaruh Transformasi Organisasi Terhadap Kompensasi}

Proses transformasi organisasi memberikan peningkatan taraf kehidupan melalui kompensasi yang didapatkan pegawai (Hakim \& Sugiyanto, 2018). Kebutuhan hidup pegawai 
sebagai individu tidak terlepas dari terpenuhinya kebutuhan material tetapi juga kebutuhan non-material seperti kebanggaan yang dapat mempengaruhi imbalan karyawan (Maulana, 2020).

H3. Transformasi organisasi PGN mempengaruhi kompensasi yang didapatkan personil PMO.

\section{Pengaruh Motivasi Terhadap Kinerja}

Pramesthi (2017) dan Hasanah \& Aima (2018) menyebutkan adanya pengaruh positif dan signifikan faktor motivasi terhadap kinerja personil. Handoko (2015) menyampaikan bahwa faktor motivasi memiliki keterkaitan terhadap semangat karyawan dalam bekerja.

H4. Motivasi bekerja personil mempengaruhi kinerja PMO.

\section{Pengaruh Kompensasi Terhadap Kinerja}

Damayanti et al. (2013) dan Maulana (2020) menyebutkan adanya pengaruh positif dan signifikan faktor kompensasi terhadap kinerja personil. Selanjutnya berdasarkan pendapat tersebut diajukan hipotesis sebagai berikut.

H5. Kompensasi yang didapatkan personil mempengaruhi kinerja PMO.

\section{Pengaruh Motivasi Sebagai Mediasi Transformasi Organisasi Terhadap Kinerja}

Implementasi transformasi organisasi harus memperhatikan adanya faktor internal berupa kepentingan personil terkait dengan kesejahteraan, pengembangan karir dan hubungan emosional maupun tekanan yang berasal dari lingkungan eksternal (Soetjipto, 2014). Selanjutnya Handoko (2015) menyampaikan bahwa faktor motivasi memiliki keterkaitan terhadap semangat karyawan dalam bekerja. Sehingga diperkirakan motivasi bekerja personil berperan sebagai mediator yang mempengaruhi hubungan implementasi transformasi organisasi terhadap kinerja.

H6. Motivasi berperan sebagai mediasi hubungan antara transformasi organisasi PGN terhadap kinerja PMO.

\section{Pengaruh Kompensasi Sebagai Mediasi Transformasi Organisasi Terhadap Kinerja}

Proses transformasi organisasi memberikan peningkatan taraf kehidupan melalui kompensasi yang didapatkan pegawai (Hakim \& Sugiyanto, 2018). Selanjutnya Damayanti dkk. (2013) dan Maulana (2020) menyebutkan adanya pengaruh positif dan signifikan faktor kompensasi terhadap kinerja personil. Sehingga diperkirakan kompensasi yang diperoleh personil berperan sebagai mediator yang mempengaruhi hubungan implementasi transformasi organisasi terhadap kinerja.

H7. Kompensasi berperan sebagai mediasi hubungan antara transformasi organisasi PGN terhadap kinerja PMO.

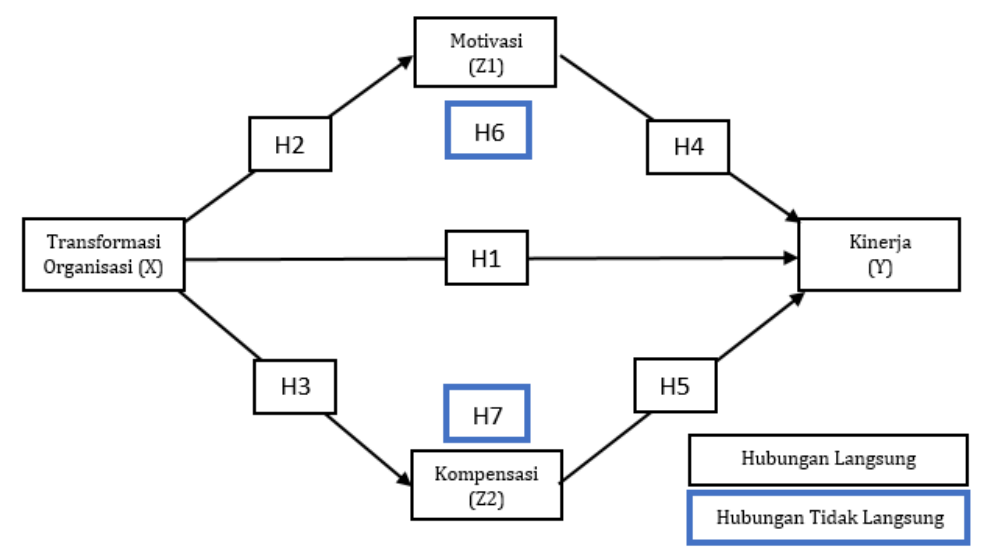

Gambar 2.

Kerangka Model Penelitian 


\section{METODE}

\section{Desain Penelitian}

Penelitian dapat digolongkan berdasarkan jenis dan sifatnya. Menurut jenisnya, penelitian yang akan dilakukan dalam menganalisis pengaruh transformasi organisasi terhadap kinerja personil pada satuan kerja PMO dengan menggunakan motivasi dan kompensasi sebagai variabel mediasi. Metode penelitian yang digunakan dalam penelitian ini adalah metode deskriptif. Sugiyono (2014) menyampaikan bahwa penelitian deskriptif adalah penelitian yang dilakukan untuk mengetahui nilai variabel mandiri, baik satu variabel atau lebih tanpa membuat perbandingan atau menghubungkan dengan variabel yang lain yang diteliti dan dianalisis sehingga menghasilkan kesimpulan.

Sedangkan berdasarkan sifatnya, Sugiyono (2014) menyebutkan dengan adanya hipotesis yang akan diuji kebenarannya melalui penelitian ini, maka sifat penelitian yang akan dilakukan adalah penelitian eksplanatori yaitu penelitian yang bermaksud menjelaskan kedudukan variabel-variabel yang diteliti serta hubungan antara satu variabel dengan variabel lainnya.

\section{Populasi dan Sampel}

Populasi dapat diartikan pada keseluruhan kelompok orang, kejadian atau hal minat yang ingin dilakukan investigasi lebih lanjut oleh peneliti. Sedangkan sampel merupakan subkelompok yang merupakan sebagian dari jumlah populasi. Melalui tahapan mempelajari sampel, peneliti akan dapat menarik kesimpulan umum tentang populasi penelitian (Sekaran \& Bougie, 2017).

Populasi dalam penelitian ini merupakan pegawai organik PMO yang bekerja di PGN. Jumlah populasi pegawai organik PMO pada saat penelitian dilakukan adalah sejumlah 118 (seratus delapan belas) orang. Sedangkan sampel yang diambil pada penelitian ini adalah pegawai organik dengan tingkat jabatan mulai dari setingkat 'Staff' hingga 'Vice President'.

Hartono (2019) menyampaikan bahwa pengambilan sampel berdasarkan populasi yang ada dapat menggunakan formula Slovin. Dengan menggunakan formula Slovin dan nilai kritis sebesar $10 \%$, maka jumlah sampel yang digunakan dalam penelitian ini adalah 54 responden.

\section{Pengukuran Variabel}

Tahapan penelitian diawali dengan menyebarkan online survey dengan mengambil sampel dari populasi dengan menggunakan kuesioner sebagai alat pengumpulan data. Kuesioner disebarkan melalui surat elektronik (e-mail) dengan menyertakan link khusus kepada tools survey secara online. Penelitian ini merupakan jenis penelitian pengujian terhadap hipotesis atas penelitian eksplanatori karena bertujuan menjelaskan pengaruh antar variabel.

Variabel transformasi organisasi mengadopsi pertanyaan kuesioner dari penelitian yang dilakukan oleh Yursil \& Huda (2016) bahwa transformasi organisasi merupakan suatu perubahan terencana mencakup struktur organisasi, strategi, SDM dan teknologi sebagai wujud organisasi dalam merespon perubahan lingkungan bisnisnya.

Sedangkan untuk variabel motivasi mengadopsi dari Putra (2017) yang menyampaikan beberapa faktor yang dapat mempengaruhi motivasi individu antara lain prestasi kerja, kesempatan untuk pengembangan diri, pekerjaan itu sendiri, kebijakan perusahaan, suasana kerja dan komunikasi yang baik dengan pimpinan.

Untuk variabel kompensasi mengadopsi pertanyaan kuesioner dari penelitian yang dilakukan oleh Maulana (2020) bahwa kompensasi sebagai segala sesuatu yang diterima pegawai sebagai balas jasa untuk kerja mereka.

Pada variabel kinerja, mengadopsi pertanyaan kuesioner dari penelitian yang dilakukan oleh Maulana (2020) yang menyebutkan delapan kriteria yang dapat digunakan dalam melakukan penilaian dan evaluasi kinerja karyawan yaitu jumlah kerja, kualitas kerja, pengetahuan, keaslian pendapat, kerjasama, kesadaran untuk dipercaya, inisiatif dan kualitas individu.

\section{Teknik Analisis}

Analisis data merupakan proses penyusunan dan mengurutkan data menjadi pola, kategori dan satuan data sehingga peneliti dapat memperoleh tema serta perumusan hipotesis seperti yang didasarkan pada data, langkah kerja dan proses dalam penelitian ini. Dengan menggunakan metode kuantitatif, penelitian ini diharapkan akan memperoleh hasil 
pengukuran yang lebih akurat terkait respon yang diberikan oleh responden melalui kuesioner, sehingga data yang berbentuk angka dapat diolah dengan menggunakan metode statistik yang telah teruji.

Analisis kuantitatif menekankan pada pengujian teori-teori melalui pengukuran variabelvariabel penelitian dalam bentuk angka dan melakukan analisis data melalui prosedur statistik. Jogiyanto (2011) menyampaikan bahwa salah satu teknik statistika yang dapat digunakan dalam pengujian dan menentukan estimasi kausalitas melalui integrasi antara analisis faktor dan analisis jalur adalah Structural Equation Modelling (SEM). Adanya fleksibilitas dan kemudahan PLS dalam melakukan analisis teknik statistika mendorong peneliti untuk menggunakan program 'Smart-PLS' versi 3.3.3 yang tersedia pada www.smartpls.com dalam penelitian ini. Adapun secara garis besar langkah-langkah yang perlu dilakukan oleh peneliti dalam menggunakan 'Smart-PLS' terutama dengan model penelitian yang menggunakan variabel mediasi, dimulai dari pengujian model pengukuran (outer model), pengujian model struktural (inner model) hingga pengujian hipotesis.

\section{HASIL DAN PEMBAHASAN}

Penelitian ini menggunakan metode analisis statistika program Smart-PLS versi 3.3.3. Adapun latar belakang pemilihan PLS antara lain kemudahan dan fleksibilitas PLS untuk mengakomodir jumlah sampel yang relatif sedikit (kurang dari 100 sampel), data yang belum memenuhi uji normalitas dan tidak mensyaratkan adanya dasar teori yang kuat dalam penelitian pengembangan.

Tabel 1.

Hasil Pengujian Hipotesis

\begin{tabular}{|l|l|l|l|}
\hline Hipotesis & $\begin{array}{l}\text { T- } \\
\text { statistic }\end{array}$ & P-value & Keterangan \\
\hline Transformasi Organisasi (X) $\rightarrow$ Kinerja (Y) & 4,075 & 0,000 & Diterima \\
\hline $\begin{array}{l}\text { Transformasi Organisasi (X) } \rightarrow \text { Motivasi } \\
(Z 1)\end{array}$ & 8,841 & 0,000 & Diterima \\
\hline $\begin{array}{l}\text { Transformasi Organisasi (X) } \rightarrow \text { Kompensasi } \\
(Z 2)\end{array}$ & 5,585 & 0,000 & Diterima \\
\hline Motivasi (Z1) $\rightarrow$ Kinerja (Y) & 4,543 & 0,000 & Diterima \\
\hline Kompensasi (Z2) $\rightarrow$ Kinerja (Y) $\rightarrow$ Motivasi & 4,220 & 0,001 & Diterima \\
\hline $\begin{array}{l}\text { Transformasi Organisasi (X) } \\
(Z 1) \rightarrow \text { Kinerja (Y) }\end{array}$ & 0,000 & $\begin{array}{l}\text { Partial } \\
\text { Mediation }\end{array}$ \\
\hline $\begin{array}{l}\text { Transformasi Organisasi (X) } \rightarrow \text { Kompensasi } \\
(\text { Z2) } \rightarrow \text { Kinerja (Y) }\end{array}$ & 2,751 & 0,003 & $\begin{array}{l}\text { Partial } \\
\text { Mediation }\end{array}$ \\
\hline
\end{tabular}

Pembahasan hasil penelitian dilakukan untuk memperoleh argumentasi ilmiah dari hasil pengujian hipotesis dalam mendukung maupun menolak penelitian-penelitian terdahulu yang dijadikan referensi dalam penelitian ini sebagaimana yang telah disebutkan sebelumnya. Adapun pembahasan hasil penelitian untuk hubungan langsung (direct effects) dilakukan pada 'Hipotesis 1 sd. 5' sedangkan untuk hubungan tidak langsung (indirect effects) dengan adanya jalur mediasi dilakukan pada 'Hipotesis 6 dan 7' dengan penjabaran sebagai berikut.

a. Transformasi organisasi PGN mempengaruhi kinerja PMO

Mengacu pada nilai T-statistic dalam Tabel 6. untuk hubungan langsung (direct effects) antara transformasi organisasi sebagai variabel eksogen berpengaruh secara signifikan terhadap kinerja PMO sebagai variabel endogen dengan nilai sebesar 4,075 $>T$-statistic dan P-value $<0,05$.

Adapun tujuan utama transformasi organisasi adalah untuk mencari metode baru atau memperbaiki pemanfaatan sumber daya dan kemampuan yang dimiliki organisasi dengan maksud untuk meningkatkan kemampuan organisasi dalam menciptakan nilai tambah dan memperoleh target kinerja yang di-inginkan oleh para pemangku kepentingan (Susanto, 2016). 
Berdasarkan tanggapan responden personil pada lingkup PMO diketahui bahwa jabatan middle management (Section Head dan Department Head) mendominasi hingga mencapai $\pm 70 \%$ dalam memberikan pandangan adanya pengaruh cukup kuat antara variabel transformasi organisasi terhadap kinerja PMO sebagai satuan kerja. Sehingga hal tersebut dapat menggambarkan bahwa proses implementasi transformasi organisasi yang didukung secara penuh oleh seluruh level jabatan akan dapat meningkatkan kinerja individu sebagai faktor fundamental dari tercapainya sasaran organisasi.

Hal ini menunjukkan Hipotesis 1 penelitian dapat diterima sekaligus mendukung pendapat Yursil \& Huda (2016) yang menyampaikan adanya pengaruh positif dan signifikan dari implementasi transformasi organisasi terhadap kinerja pegawai sekaligus menolak pendapat Widjajanti (2009) yang menyampaikan bahwa transformasi organisasi memberikan pengaruh negatif dan tidak signifikan terhadap kinerja perusahaan.

b. Transformasi organisasi PGN mempengaruhi motivasi bekerja personil PMO

Mengacu pada nilai T-statistic dalam Tabel 6. untuk hubungan langsung (direct effects) antara transformasi organisasi sebagai variabel eksogen berpengaruh secara signifikan terhadap motivasi sebagai variabel endogen dengan nilai sebesar 8,841 > $T$-statistic dan $P$-value $<0,05$.

Implementasi transformasi organisasi harus memperhatikan adanya dampak terhadap kepentingan personil terkait dengan kesejahteraan, pengembangan karir dan hubungan emosional maupun tekanan yang berasal dari lingkungan eksternal (Soetjipto, 2014). Faktor internal lainnya dapat berupa motivasi, tujuan, harapan dan lainnya sedangkan faktor eksternal berupa lingkungan fisik dan non-fisik perusahaan (Handoko, 2015).

Berdasarkan hasil penelitian dapat diketahui bahwa implementasi transformasi organisasi sangat kuat mempengaruhi motivasi personil PMO dimana dalam penelitian ini diperoleh nilai $f$-squared (effect size) tertinggi sebesar 0,810 untuk pengaruh transformasi organisasi sebagai variabel eksogen terhadap motivasi bekerja personil dibandingkan terhadap kompensasi $(0,505)$ dan kinerja $(0,233)$ sebagai variabel endogen yang dipengaruhinya.

Implementasi transformasi organisasi yang disertai dengan adanya program peningkatan kapabilitas dan kapasitas personil dapat memberikan pengaruh yang signifikan terhadap meningkatnya motivasi bekerja personil PMO. Berdasarkan pada tanggapan responden PMO diketahui dengan rentang usia dominan pada $31-40$ tahun dan masa kerja 9 - 16 tahun membutuhkan program retensi pegawai berupa pengembangan diri dan peningkatan karir dalam menyeimbangkan dengan tanggung jawab yang diberikan oleh perusahaan dalam meningkatkan motivasi personil dan keterikatannya dengan organisasi.

Hal ini menunjukkan Hipotesis 2 penelitian diterima dan menyatakan bahwa transformasi organisasi dapat mempengaruhi secara signifikan kepada motivasi personil sebagai anggota organisasi.

c. Transformasi organisasi PGN mempengaruhi kompensasi yang didapatkan personil PMO

Mengacu pada nilai T-statistic dalam Tabel 6. untuk hubungan langsung (direct effects) antara transformasi organisasi sebagai variabel eksogen berpengaruh secara signifikan terhadap kompensasi yang diperoleh personil PMO sebagai variabel endogen dengan nilai sebesar 5,585 $>$ T-statistic dan $P$-value $<0,05$.

Proses transformasi organisasi memberikan peningkatan taraf kehidupan melalui kompensasi yang didapatkan pegawai pada industri batik (Hakim \& Sugiyanto, 2018). Kebutuhan hidup pegawai sebagai individu tidak terlepas dari terpenuhinya kebutuhan material tetapi juga kebutuhan non-material seperti kebanggaan yang dapat mempengaruhi imbalan karyawan (Maulana, 2020).

Berdasarkan hasil penelitian dapat diketahui bahwa implementasi transformasi organisasi pada lingkup PMO dirasakan memberikan pengaruh kuat terhadap 
kompensasi yang didapatkan personilnya. Adanya transformasi organisasi senantiasa menimbulkan konsekuensi berupa perubahan struktur organisasi, penyesuaian beban kerja hingga mutasi personil baik dari kantor pusat kepada unit kerja maupun sebaliknya. Konsekuensi tersebut perlu diantisipasi oleh perusahaan dalam melakukan penyesuaian pemberian kompensasi kepada personil untuk memaksimalkan pencapaian tujuan transformasi organisasi yang telah ditetapkan oleh top management.

Hal ini menunjukkan Hipotesis 3 penelitian dapat diterima sekaligus mendukung pendapat Hakim \& Sugiyanto (2018) yang menyampaikan bahwa dengan adanya manajemen perubahan atau transformasi organisasi dapat meningkatkan taraf hidup pegawai sebagai dampak dari peningkatan kompensasi yang diberikan perusahaan.

d. Motivasi bekerja personil mempengaruhi kinerja PMO

Mengacu pada nilai T-statistic dalam Tabel 6. untuk hubungan langsung (direct effects) antara motivasi bekerja personil PMO sebagai variabel eksogen berpengaruh secara signifikan terhadap kinerja sebagai variabel endogen dengan nilai sebesar 4,543

T-statistic dan $P$-value $<0,05$.

Pramesthi (2017) dan Hasanah \& Aima (2018) menyebutkan adanya pengaruh positif dan signifikan faktor motivasi terhadap kinerja personil masing-masing pada lingkup koperasi di Jember dan pada Badan Manajemen PPPIJ. Sedangkan (Handoko, 2015) menyampaikan bahwa faktor motivasi memiliki keterkaitan terhadap semangat karyawan dalam bekerja.

Berdasarkan hasil penelitian dapat diketahui bahwa pengelolaan motivasi personil pada lingkup PMO, antara lain pencapaian prestasi kerja, tersedianya jalur-jalur pengembangan diri, adanya dukungan DAK (Dokumen Acuan Kerja) yang fleksibel, tersedianya aspek motivator serta dukungan kebijakan perusahaan yang mengedepankan aspek K3 sangat mempengaruhi kinerja personil PMO dimana dalam penelitian ini diperoleh nilai $f$-squared (effect size) tertinggi sebesar 0,305 untuk pengaruh motivasi sebagai variabel eksogen terhadap kinerja sebagai variabel endogen dibandingkan terhadap pengaruh kompensasi $(0,215)$ dan transformasi organisasi $(0,233)$ sebagai variabel eksogen.

Hal ini menunjukkan Hipotesis 4 penelitian dapat diterima sekaligus mendukung pendapat Pramesthi (2017) dan pendapat Hasanah \& Aima (2018) yang menyampaikan adanya pengaruh positif dan signifikan motivasi kerja terhadap kinerja pegawai.

e. Kompensasi yang didapatkan personil mempengaruhi kinerja PMO

Mengacu pada nilai T-statistic dalam Tabel 6. untuk hubungan langsung (direct effects) antara kompensasi yang diperoleh personil PMO sebagai variabel eksogen berpengaruh secara signifikan terhadap kinerja sebagai variabel endogen dengan nilai sebesar 3,220 $>T$-statistic dan $P$-value $<0,05$.

Maulana (2020) menyampaikan bahwa kompensasi yang diberikan organisasi akan memuaskan dan memotivasi pegawai untuk mencapai sasaran organisasi pada lingkup koperasi di Cimahi. Penelitian yang dilakukan oleh Subakti (2013) menyebutkan adanya fenomena rendahnya kinerja karyawan cafe ' $\mathrm{X}$ ' karena faktor gaji dan tidak adanya insentif yang diberikan oleh manajemen.

Berdasarkan hasil penelitian dapat diketahui bahwa kompensasi yang diterima oleh personil mempengaruhi kinerja satuan kerja PMO. Adanya pemberian kompensasi yang seimbang dengan tugas dan tanggung jawab yang diberikan oleh perusahaan tentunya dapat meningkatkan kinerja personil sebagai faktor fundamental pencapaian kinerja organisasi. Mengacu pada nilai $f$-squared (effect size) terendah dimana variabel kompensasi sebagai variabel eksogen hanya berpengaruh sebesar 0,215 terhadap kinerja sebagai variabel endogen dibandingkan transformasi organisasi $(0,233)$ dan motivasi $(0,305)$ hal ini menggambarkan bahwa faktor kompensasi memiliki porsi peran yang kurang dominan terhadap kinerja apabila 
dibandingkan dengan faktor transformasi organisasi maupun motivasi bekerja personil.

Atas penjelasan tersebut menunjukkan Hipotesis 5 penelitian dapat diterima sekaligus mendukung pendapat Maulana (2020) dan Damayanti dkk. (2013) yang menyampaikan adanya pengaruh positif dan signifikan kompensasi yang diterima terhadap kinerja pegawai.

f. Motivasi berperan sebagai mediasi hubungan antara transformasi organisasi PGN terhadap kinerja PMO

Mengacu pada nilai T-statistic dalam Tabel 6. untuk hubungan tidak langsung (indirect effects) antara transformasi organisasi dengan kinerja PMO melalui mediasi (mediator) motivasi bekerja personil PMO dengan nilai sebesar 4,015 > T-statistic dan $P$-value $<0,05$. Hal ini menunjukkan Hipotesis 6 penelitian dapat diterima bahwa motivasi bekerja personil dapat menjadi mediasi dan mempengaruhi secara signifikan hubungan antara transformasi organisasi terhadap kinerja PMO.

Mempertimbangkan hasil penelitian yang dilakukan pada lingkup PMO diketahui bahwa pengelolaan motivasi dapat mempengaruhi implementasi transformasi organisasi terhadap kinerja PMO. Mengacu pada tanggapan responden PMO diketahui bahwa dengan rentang usia dominan pada $31-40$ tahun dan masa kerja 9 - 16 tahun, maka dengan adanya implementasi program supervisi oleh atasan kepada personilpersonil PMO dapat meningkatkan motivasi bekerja sehingga pekerjaan diselesaikan dengan baik secara bertanggung jawab dan memenuhi kualitas maupun kuantitas yang telah ditetapkan oleh perusahaan.

Berdasarkan pada penjelasan efek mediasi oleh Cepeda dkk. (2017) dan hubungan langsung (direct effects) antara transformasi organisasi yang berpengaruh signifikan terhadap kinerja dalam Hipotesis 1, maka diketahui terdapat 'Partial-mediation Effects' dalam hubungan antara transformasi organisasi terhadap kinerja melalui motivasi sebagai faktor mediasi.

g. Kompensasi berperan sebagai mediasi hubungan antara transformasi organisasi PGN terhadap kinerja PMO

Mengacu pada nilai T-statistic dalam Tabel 6. untuk hubungan tidak langsung (indirect effects) antara transformasi organisasi dengan kinerja PMO melalui mediasi (mediator) kompensasi yang diperoleh personil PMO dengan nilai sebesar 2,751 > Tstatistic

dan

$P$-value $<0,05$. Hal ini menunjukkan Hipotesis 7 penelitian dapat diterima bahwa kompensasi yang didapatkan personil dapat menjadi mediasi dan mempengaruhi secara signifikan hubungan antara transformasi organisasi terhadap kinerja PMO.

Mempertimbangkan hasil penelitian yang dilakukan pada lingkup PMO diketahui bahwa pemberian kompensasi yang tepat dapat mempengaruhi tercapainya tujuan transformasi organisasi terhadap peningkatan kinerja PMO. Hal ini dapat diartikan bahwa melalui penyesuaian kompensasi yang didapatkan personil PMO sebagai konsekuensi atas beban kerja pasca transformasi organisasi, maka pencapaian atas target kinerja yang ditetapkan oleh top management dapat dicapai secara optimal.

Berdasarkan penjelasan efek mediasi oleh Cepeda dkk. (2017) dan hubungan langsung (direct effects) antara transformasi organisasi yang berpengaruh signifikan terhadap kinerja dalam Hipotesis 1, maka diketahui terdapat 'Partial-mediation Effects' dalam hubungan antara transformasi organisasi terhadap kinerja melalui kompensasi sebagai faktor mediasi.

\section{KESIMPULAN}

Kesimpulan

Berdasarkan hasil penelitian yang dilakukan pada satuan kerja Project Management Office ('PMO') di PT Perusahaan Gas Negara Tbk. ('PGN') terkait pengaruh transformasi organisasi terhadap kinerja dengan menggunakan motivasi dan kompensasi sebagai mediasi, dapat ditarik kesimpulan sebagai berikut:

1. Transformasi organisasi PGN memiliki pengaruh signifikan terhadap kinerja PMO, 
Motivasi bekerja personil PMO dan Kompensasi personil PMO.

2. Motivasi bekerja personil dan Kompensasi memiliki pengaruh signifikan terhadap kinerja PMO.

3. Motivasi bekerja personil berperan sebagai mediasi hubungan antara transformasi organisasi PGN terhadap kinerja PMO. Hal ini menunjukkan bahwa motivasi bekerja personil dapat menjadi faktor mediasi (mediator) yang memiliki pengaruh kuat dalam hubungan antara implementasi transformasi organisasi PGN terhadap pencapaian kinerja PMO.

4. Kompensasi yang didapatkan personil berperan sebagai mediasi hubungan antara transformasi organisasi PGN terhadap kinerja PMO. Hal ini menunjukkan bahwa kompensasi yang didapatkan personil dapat menjadi faktor mediasi (mediator) yang memiliki pengaruh kuat dalam hubungan antara implementasi transformasi organisasi PGN terhadap pencapaian kinerja PMO.

\section{Keterbasan dan Saran}

Penelitian ini masih memiliki beberapa keterbatasan, maka dapat disampaikan saran-saran kepada akademisi serta kepala satuan kerja Project Management Office ('PMO') sebagai obyek penelitian maupun kepala satuan kerja Human Capital Management ('HCM') sebagai satuan kerja pengelola SDM di PT Perusahaan Gas Negara Tbk. antara lain sebagai berikut:

1. Mengacu pada hasil uji koefisien determinasi ( $R$-squared) untuk kinerja sebagai variabel endogen diperoleh nilai sebesar $54,3 \%$ yang dipengaruhi oleh transformasi organisasi, motivasi dan kompensasi sebagai variabel eksogen, maka dapat disarankan kepada peneliti selanjutnya agar dapat menggunakan variabel-variabel eksogen lainnya yang dapat memberikan pengaruh signifikan terhadap kinerja untuk mendapatkan hasil penelitian dengan hubungan determinasi yang lebih kuat terhadap variabel terikatnya.

2. Fokus penelitian dan penentuan responden dapat ditetapkan pada level jabatan tertentu, sehingga hasil penelitian dapat memberikan saran yang lebih implementatif dan konkret dalam rangka peningkatan kinerja personil sebagai anggota organisasi.

3. Terhadap implementasi transformasi organisasi selanjutnya, terutama yang disebabkan oleh faktor eksternal seperti adanya perubahan regulasi, kompetisi maupun ketetapan dari pemangku kepentingan (stakeholder), maka hendaknya PGN sebagai organisasi dapat menyiapkan strategi antisipasi maupun mitigasi dalam meningkatkan tingkat keberhasilan (success ratio) program transformasi organisasi yang berfokus dalam pengelolaan SDM agar pencapaian kinerja perusahaan dapat tercapai secara optimal.

4. Adapun program-program yang dapat direalisasikan untuk meningkatkan kinerja personil, antara lain:

a. Peningkatan motivasi bekerja personil yang diwujudkan dalam bentuk pengakuan prestasi kerja; tersedianya fasilitas untuk pengembangan diri personil (soft-skill dan hard-skill); fleksibilitas penyelesaian pekerjaan sesuai dengan pedoman dan langkah kerja yang berlaku; adanya pengakuan dan penghargaan atas pencapaian kerja; serta dukungan top management dalam bentuk kebijakan perusahaan yang mengedepankan proses supervisi pekerjaan dan aspek K3.

b. Penyesuaian kompensasi yang didapatkan personil sesuai dengan beban kerja dan tanggung jawab yang diberikan oleh perusahaan kerja hingga adanya dampak berupa mutasi personil baik dari kantor pusat kepada unit kerja maupun sebaliknya.

c. Peningkatan kapabilitas dan kapasitas personil sebagai langkah antisipasi dan mitigasi celah (gap) pemahaman implementasi transformasi organisasi yang ditetapkan oleh top management sebagai bagian dari strategi perusahaan kedepan. 


\section{REFERENSI}

Andriani, R. \& Putra, WBTS. (2019). The intersection of marketing and human resources dicipline: employer brand equity as a mediator in recruitment process. International Journal of Innovative Science and Research Technology (4): 465-475.

Cepeda, G., Nitzl, C. \& Roldan, J. L. (2017). Mediation Analyses in Partial Least Squares Structural Equation Modeling - Guidelines \& Empirical Examples. Industrial Management \& Data Systems.

Damayanti, A. Susilaningsih \& Sumaryati, S. (2013). Pengaruh Kompensasi dan Motivasi Kerja Terhadap Kinerja Karyawan Perusahaan Daerah Air Minum (PDAM) Surakarta. Jupe UNS, Volume 2, Nomor 1, Halaman 155-168.

Fadilah, F. (2018). Pengaruh Kompetensi Pegawai, Motivasi Kerja dan Kompensasi Yang Diberikan Terhadap Kinerja Pejabat Pengelola Informasi dan Dokumentasi (PPID) di Pemerintah Kota Lubuklinggau. Jakarta : Tugas Akhir Program Magister (TAPM) Program Pascasarjana, Universitas Terbuka.

Hair, J. F. Jr., Anderson, R. E., Tatham, R. L. \& Black, W. C. (1995). Multivariate Data Analysis (3rd Edition). New York: Macmillan.

Hakim, L. \& Sugiyanto, E. (2018). Manajemen Perubahan Organisasi Sebagai Upaya Peningkatan Kinerja Perusahaan di Industri Batik Laweyan Surakarta. Jurnal Manajemen dan Bisnis BENEFIT, Volume 3, Nomor 2, Halaman 55.

Handoko. (2015). Manajemen Sumber Daya Manusia (Cetakan Pertama). Bandung : Pusaka Setia.

Hartono. (2019). Metodologi Penelitian. Pekanbaru : Zanafa Publishing.

Hasanah, R. \& Aima, M. (2018). Pengaruh Perubahan Organisasi, Budaya Organisasi dan Motivasi Terhadap Kinerja Pegawai Badan Manajemen Pusat Pengkajian dan Pengembangan Islam Jakarta. Jurnal Ilmiah Manajemen dan Bisnis 'Indikator', Volume 2, Nomor 1, Halaman 71-89.

Henseler, J., Ringle, C. M. \& Sarstedt, M. (2015). A New Criterion For Assesing Discriminant Validity In Variance-Based Structural Equation Modeling. Journal of the Academy of Marketing Science, Volume 43, Halaman 115 - 135.

Indrasari, M. (2017). Kepuasan Kerja dan Kinerja Karyawan 'Tinjauan dari Dimensi Iklim Organisasi, Kreativitas Individu dan Karakteristik Pekerjaan'. Yogyakarta: Indomedia Pustaka.

Jogiyanto. (2011). Konsep dan Aplikasi Structural Equation Modeling Berbasis Varian Dalam Penelitian Bisnis. Yogyakarta : UPP STIM YKPN.

Latief, B. (2012). Faktor-faktor yang Mempengaruhi Kinerja Karyawan PT Mega Mulia Servindo di Makasar. Jurnal Manajemen dan Akuntansi, Volume 1, Nomor 2, Halaman 63.

Maulana, A. (2020). Pengaruh Kompetensi dan Kompensasi Terhadap Kinerja Pegawai Primer Koperasi Kartika Artileri Berdaya Guna Sepanjang Masa Pusat Kesenjataan Artileri Medan Kota Cimahi. Coopetition: Jurnal Ilmiah Manajemen, Volume XI, Nomor 2, Halaman 83-96.

Pramesthi, R. (2017). Pengaruh Motivasi dan Kepuasan Kerja Terhadap Kinerja Karyawan Koperasi di Kecamatan Sumbersari Jember. Jurnal Ekonomi dan Bisnis 'Growth', Volume 15, Nomor 2, Halaman 70.

Putra, D. (2017). Pengaruh Kepuasan Kerja, Motivasi Kerja dan Kepemimpinan Terhadap Organizational Citizenship Behavior dan Kinerja Karyawan PT MSH Niaga Telecom Surabaya. Surabaya : Tesis Fakultas Bisnis dan Manajemen Teknologi, Institut Teknologi Sepuluh Nopember.

Ramayah, T., Jasmine, Y. A. L., Ahmad, N. H., Halim, H. A. \& Rahman, S. A. (2017). Testing a Confirmatory Model of Facebook Usage in SmartPLS using Consistent PLS. International Journal of Business and Innovation, Volume 3, Nomor 2, Halaman 1 - 14.

Santosa, P. (2018). Metode Penelitian Kuantitatif 'Pengembangan Hipotesis dan Pengujiannya Menggunakan SmartPLS'. Yogyakarta : Penerbit ANDI.

Sanuddin, F \& Widjojo, R. (2013). Pengaruh Kepuasan Kerja dan Motivasi Kerja Terhadap Kinerja Karyawan PT Semen Tonasa. Modus Journal, Volume 25, Nomor 2, Halaman 220.

Sekaran, U. \& Bougie, R. (2017). Metoda Penelitian untuk Bisnis (6th ed.). Jakarta : Salemba Empat.

Siagian, S. (2012). Teori Pengembangan Organisasi. Jakarta : Bumi Aksara. 
Soetjipto, D. (2014). Road to Semen Indonesia, Transformasi Korporasi Mengubah Konflik Menjadi Kekuatan. Jakarta : Penerbit Buku Kompas.

Subakti, A. (2013). Pengaruh Motivasi, Kepuasan dan Sikap Kerja Terhadap Kinerja Karyawan di Café X Bogor. Binus Business Review, Volume 4, Nomor 2, Halaman 605.

Sugiyono. (2014). Metode Penelitian Manajemen. Bandung : Alfabeta.

Susanto, I. (2016). Strategy-LED Transformation. Jakarta : PT Elex Media Komputindo.

Syaifuddin. (2018). Motivasi \& Kinerja Pegawai 'Pendekatan Riset'. Yogyakarta : Indomedia Pustaka.

Widjajanti, K. (2009). Transformasi Organisasional Privatisasi BUMN di Indonesia. Jurnal EKOBIS, Volume 10, Nomor 2, Halaman 322-333.

Yursil, A. \& Huda, N. (2016). Pengaruh Transformasi dan Budaya Organisasi Terhadap Kepuasan Serta Kinerja Pegawai BPJS Kesehatan. Journal of Economics and Business Aseanomics (JEBA), Volume 1, Nomor 1, Halaman 5 \& 6.

\section{Profil Penulis}

Armynas Handyas Wijayatma memperoleh gelar Sarjana dari Universitas Pembangunan 'Veteran' Yogyakarta dan Magister Manajemen dari Universitas Terbuka, Indonesia. Saat ini aktif sebagai praktisi risk management pada salah satu BUMN terkemuka di Indonesia. Minat penelitiannya dalam bidang sumber daya manusia (SDM) dan implementasi manajemen risiko korporat.

Liswandi Ph.D memperoleh gelar Doktor Manajemen (Ph.D in Management by Research) dari Universiti Selangor (Unisel), Malaysia. Beliau memiliki pengalaman kerja beberapa tahun di berbagai industri, dan saat ini menjadi asisten Profesor bidang Manajemen Sumber Daya Manusia di School of Business, President University, Bekasi-Indonesia. Minat penelitiannya di bidang Manajemen Sumber Daya Manusia dan telah menerbitkan artikelnya di beberapa jurnal internasional dan nasional.

Dr. Sugilar, M.Pd. memperoleh gelar Magister Pendidikan dan Doktor dari Universitas Negeri Jakarta. Beliau saat ini aktif mengajar sebagai dosen tetap dan sekaligus guru besar di Universitas Terbuka, Indonesia. Minat penelitiannya di bidang pendidikan matematika dan telah menerbitkan artikelnya di beberapa jurnal internasional dan nasional. 